\title{
Monitoring cell energy, physiological functions and grain yield in field-grown mung bean exposed to exogenously applied polyamines under drought stress
}

\author{
Saeid Ghassemi ${ }^{1}$ Salar Farhangi-Abriz ${ }^{1}$ Reza Faegi-Analou ${ }^{2}$ Mansour Ghorbanpour ${ }^{3, *}$ \\ Behnam Asgari Lajayer ${ }^{4}$ \\ ${ }^{1}$ Department of Plant Eco-physiology, Faculty of Agriculture, University of Tabriz, Tabriz, Iran \\ ${ }^{2}$ Department of Agronomy, Faculty of Agriculture, Islamic Azad University of Roudehen, Tehran, Iran \\ ${ }^{3}$ Department of Medicinal Plants, Faculty of Agriculture and Natural Resources, Arak University, 38156-8- \\ 8349 Arak, Iran. ${ }^{4}$ Young Researchers and Elite Club, Tabriz Branch, Islamic Azad University, Tabriz, Iran. \\ *Corresponding author: m-ghorbanpour@araku.ac.ir
}

\begin{abstract}
Polyamines are new plant growth regulators and intracellular messengers that regulate plant growth, development, and responses to abiotic environmental stresses. However, little is known about the impact of different polyamines on physiological and biochemical processes of field-grown plants exposed to water deficit stress. A two-year field experiment was conducted as a split-plot based on a randomized complete block design with four replications. Water treatments (Irrigation after 70 and $170 \mathrm{~mm}$ evaporation from class A evaporation pan) were assigned to main plots, and foliar application of polyamines including Putrescine, Spermidine and Spermine (at 0 and $0.1 \mathrm{mM}$ ) was apportioned to subplots. Average of two years results showed that compared with control, water stress significantly $(P<0.05)$ reduced adenosine three phosphate (ATP), chlorophyll content index $(\mathrm{CCI})$ and chlorophyll stability index (CSI), rubisco activity, efficiency of photosystem II (Fv/Fm), endogenous polyamine contents, membrane stability index (MSI), nitrogen $\left(\mathrm{N}_{2}\right)$, potassium $\left(\mathrm{K}^{+}\right)$, calcium $\left(\mathrm{Ca}^{2+}\right)$, magnesium $\left(\mathrm{Mg}^{2+}\right)$, and grain yield, while polyamine oxidase activity, antioxidant enzymes activity, reactive oxygen species (ROS) and lipid peroxidation (MDA) increased significantly $(P<0.05)$ upon exposure to water deficit stress. However, exogenous application of polyamines improved ATP content, CCI, CSI, rubisco activity, Fv/Fm, endogenous polyamine content, MSI, antioxidant enzymes activity, $\mathrm{N}_{2}, \mathrm{~K}^{+}, \mathrm{Ca}^{2+}, \mathrm{Mg}^{2+}$, and grain yield, while decreased ROS level and MDA content. Compared with the other polyamines, Putrescine showed better effects on physiological, biochemical and agronomical performance in mung bean plants under both irrigation treatments.
\end{abstract}

Keywords: Antioxidant enzymes, Cell redox, Drought stress, Photosystem II, Polyamines, Reactive oxygen species. 


\section{Introduction}

Grain legumes, including pigeon pea, chickpea, cowpea, lentil, dry pea, and mung bean are the major dietary source of protein for vegetarians, and constitute an essential part of the daily food in various forms worldwide. The mung bean (Vigna radiata L.), also known as green gram, has been mostly grown in Asia, Africa, Australia, South America and united states. It is one of the most nutritious grain legumes used in many regions of the world. Although mung bean is a moderately drought-tolerant crop and performs fine under low soil moisture, severe water stress can result in yield loss (Butt and Batool, 2010).

In a great part of the farming areas in the world, water deficit is an important factor limiting growth and productivity of the crops. Water stress occurs when water potentials in the root zones are sufficiently negative to reduce water accessibility to sub-optimal levels of plant growth and development. Under both the wild and cultivated conditions, plants often experience a multitude of environmental perturbations such as drought. A large proportion of the world agronomy depends on rainfall for watering, as good quality of water source is highly limited or unpredictable. In many of such arid regions, crops are frequently affected by severe drought. Drought stress causes a significant reduction in plant water uptake and cell turgor potential, resulted in reduced growth and productivity (Baiazidi-Aghdam et al., 2016). Photosynthesis and cell growth are the most essential processes which are affected by osmotic stress. At the water deficit, plant leaves are dehydrated, and subsequently photosynthesis is reduced. The reduction in photosynthesis of dehydrated leaves is frequently caused by the decline in stomatal conductance and transpiration (Limousin et al., 2010). As a result of the decreasing in transpiration rate, leaf temperature increases, leading to the combination of heat and drought damage. In such conditions, the increase in the activity of chlorophyllase (the key enzyme in chlorophyll metabolism) and reduction in adenosine triphosphate (ATP) in plant cells reduced the photosynthetic activities. Furthermore, water deficit inhibited the photosynthetic enzymes activities such as Ribulose-1,5-bisphosphate carboxylase (rubisco) and affected the crop productivity. Decrease in rubisco activity can therefore be caused by a reduction in rubisco protein content, inhibition of the carbamylated enzyme, or an increase in non-carbamylated rubisco forms (Flexas et al., 2006). Reduction in photosynthesis at the molecular level is associated with the limited electron transport components through photosystem II (PSII) and/or with structural damages to the redox active catalytic sites of PSII. The chlorophyll a fluorescence shows the maximum efficiency of photochemical activities in PSII. Low values of this efficiency expose a specific phenomenon of biochemical injury to PSII centers. Chlorophyll a fluorescence lets us to study the diverse applied levels of photosynthesis indirectly, such as developments at the main light reactions, pigment levels, thylakoid electron transportation reactions and dark enzymatic responses. Physiological stresses that disturb PSII efficiency leads to a decrease in the Fv/ Fm ratio (Baker and Rosenqvist, 2004).

Water deficit can cause oxidative stress in plants, under this condition different reactive oxygen species (ROS) such as superoxide radical $\left(\mathrm{O}_{2}^{--}\right)$and hydrogen peroxide $\left(\mathrm{H}_{2} \mathrm{O}_{2}\right)$ is excessively produced. ROS can hurt cell membranes, nucleic acids, and proteins, affecting metabolic imbalances in plants. Water stress also may damage cell membranes through leakage of the free radicals and depletion of enzyme activities, causing lipid peroxidation with consequent over production of malondialdehyde (MDA) (Mohammadi et al., 2008). MDA is a secondary breakdown and final product of lipid per- 
oxidation process, and widely accepted mechanism for estimating lipid peroxidation and oxidative damage in plant cells and tissues. At the same time, plants produce a diversity of antioxidant molecules that counteract the excessive generation of ROS in response to water deficit stress (Munne-Bosch and Penuelas, 2003).

Polyamines, one of the oldest groups of natural compounds, exist in almost all living organisms and play vital roles in many physiological processes such as cell evolution and development, and response to environmental stresses such as water deficit. Also, these growth substances are involved in the regulation of many basic cellular processes, including transcription, DNA replication, translation, modulation of enzyme activities, cell proliferation, membrane stability, cellular cation balance and ATP synthesis. The putrescine, spermidine and spermine are the main polyamines in plant cells. Many studies exhibit that polyamines could act as cellular signals involved in cross talk with hormonal pathways such as abscisic acid regulation of abiotic stress responses (Mustafavi et al., 2018). A striking increase of polyamines occurs under the deprivation of cations such as $\mathrm{K}^{+}$and $\mathrm{Mg}^{2+}$. Although, according to the literature, polyamines appear to be essential growth regulators, their precise physiological function and mechanism of action remain still unknown. Thus, the objective of the present research was to elucidate the influence of polyamines on physiological and biochemical parameters of mung bean under drought stress.

\section{Material and Methods}

\subsection{Experimental conditions}

Two farm experiments were conducted as a split-plot factorial experiment in a randomized complete block design (RCBD) with four replications at the Agricultural Research Center of East Azerbaijan, Maragheh, Iran (Latitude $37^{\circ} 38^{\prime} \mathrm{N}$, longitude $46^{\circ} 25^{\prime} \mathrm{E}$, altitude $1477 \mathrm{~m}$ above mean sea level). The basic soil properties are shown in Table 1. Also, climatic features during the experiments (125 days) are shown in table 1. Irrigation intervals, including irrigation after 70 and $170 \mathrm{~mm}$ evaporation from class A pan were assigned to the main plots and foliar spraying of polyamines including Putrescine $(0.1 \mathrm{mM})$, Spermidine $(0.1 \mathrm{mM})$ and Spermine $(0.1 \mathrm{mM})$, and control (without using polyamines) were allocated to subplots.

Table 1. Physical and chemical characteristics of the experimental field soil, and mean of rainfall, temperature, evapotranspiration and relative humidity during the cropping years (2015 and 2016).

\begin{tabular}{|c|c|c|c|c|c|}
\hline Property & & Sand (\%) & Silt (\%) & Clay (\%) & $\mathrm{pH}$ \\
\hline \multirow{5}{*}{$\begin{array}{c}\text { Edaphic } \\
\text { characteristics }\end{array}$} & 2015 & 60 & 30 & 10 & 7.4 \\
\hline & 2016 & 60 & 30 & 10 & 7.2 \\
\hline & & $\begin{array}{c}\mathrm{EC}\left(\mathrm{mmos} \mathrm{cm}^{-}\right. \\
1)\end{array}$ & $\mathrm{N}\left(\mathrm{kg} \mathrm{ha}^{-1}\right)$ & $\mathrm{P}\left(\mathrm{kg} \mathrm{ha}^{-1}\right)$ & $\mathrm{K}\left(\mathrm{kg} \mathrm{ha}^{-1}\right)$ \\
\hline & 2015 & 0.11 & 105 & 14.7 & 195 \\
\hline & 2016 & 0.11 & 110 & 13.5 & 189 \\
\hline \multirow{3}{*}{$\begin{array}{c}\text { Climatic } \\
\text { characteristics }\end{array}$} & & $\begin{array}{c}\text { Rainfall } \\
\text { (mm) }\end{array}$ & $\begin{array}{c}\text { Temperature } \\
\left({ }^{\circ} \mathrm{C}\right)\end{array}$ & $\begin{array}{c}\text { Evapotranspiration } \\
\left(\mathrm{mm} \text { day }^{-1}\right)\end{array}$ & $\begin{array}{c}\text { Humidity } \\
(\%)\end{array}$ \\
\hline & 2015 & 62.8 & 19.8 & 9.7 & 34.2 \\
\hline & 2016 & 57.2 & 21.3 & 10.3 & 28.5 \\
\hline
\end{tabular}


Mung bean seeds (Cultivar ILC482, a high-yielding cultivar and widely used in commercial level) were obtained from the Seed and Plant Improvement Research Institute, Karaj, Iran. Seeds were sterilized with 70\% ethanol for $2 \mathrm{~min}$ and washed three times with deionized water thoroughly. Each plot consisted of six rows of $3.5 \mathrm{~m}$ lengths; spaced $25 \mathrm{~cm}$ apart. All plots were watered immediately after sowing the seeds, but after seedling establishment, irrigations were performed according to the employed treatments. After seedling establishment, plant densities adjusted to 50 plants $\mathrm{m}^{-2}$. Polyamines were sprayed on plants at vegetative (30 days after sowing) and flowering (57 days after sowing) stages in accordance with the treatments (with spraying $100 \mathrm{ml} \mathrm{m}^{-2}$ in each spraying time). The following measurements were performed on plants in all experimental units about two weeks after the last spraying.

\subsection{Adenosine triphosphate content in plant cells}

The total adenosine triphosphate (ATP) content was recorded weakly [(begins from the first day after spraying), in all of the tested parameters, last day of data recording was the end of the seed maturation stage (about 68 days after last spraying)] by luciferinluciferase assay using a Luminometer (model: novalum, Charm Sciences, Lawrence, Massachusetts, USA). The ATP of cells was extracted in $2 \mathrm{mM}$ ethylenediamine tetraacetic acid (EDTA) with 4\% trichloracetic acid (TCA) (Larsson and Olsson, 1979).

\subsection{Chlorophyll content index and Chlorophyll stability index}

Chlorophyll content index (CCI) was measured with a portable chlorophyll meter (CCM-200, Opti-Sciences, USA). Briefly, five plants were selected in each plot and the CCI of the upper, middle and lower leaves of each plant was measured weakly at 10 am (Ante meridiem).
Two weeks after the last spraying, the chlorophyll stability index (CSI) was estimated spectrophotometricaly using the method of Koleyoreas (1958) (100 Conc UV Visible Spectrophotometer, Varian, California, USA).

\subsection{Efficiency of photosystem II}

At the end of the seed maturation stage maximum efficiency of photosystem II $\left(\mathrm{F}_{\mathrm{v}} / \mathrm{F}_{\mathrm{m}}\right)$ was determined using a portable chlorophyll fluorometer (Handy PEA, Hansatech, UK). Dark-adapted leaves (30 min) were initially exposed to the weak modulate measuring beam (photon flux density of $0.5 \mu \mathrm{mol} \mathrm{m}^{-2} \mathrm{~s}^{-1}$ ) of the instrument, followed by exposure to saturated white light (photon flux density of $>10,000 \mu \mathrm{mol} \mathrm{m}^{-2} \mathrm{~s}^{-1}$ ) to estimate the initial $\left(\mathrm{F}_{0}\right)$ and maximum $\left(\mathrm{F}_{\mathrm{m}}\right)$ fluorescence values, respectively. Fv/Fm was calculated by following equation:

$$
\mathrm{Fv} / \mathrm{Fm}=(\mathrm{Fm}-\mathrm{F} 0) / \mathrm{Fm}
$$

\subsection{Rubisco activity}

Rubisco activity was determined at the end of the seed maturation stage according to the method of Lobo et al., (2015) and it was spectrophotometrically measured by rate of NADH oxidation at $340 \mathrm{~nm}$ (100 Conc UV Visible Spectrophotometer, Varian, California, USA). In this way the assay buffer consisted of $100 \mathrm{mM}$ bicine, $25 \mathrm{mM} \mathrm{KHCO}_{3}, 20 \mathrm{mM} \mathrm{MgCl}$, $3.5 \mathrm{mM}$ ATP, 5 $\mathrm{mM}$ phosphocreatine, 80 nkat G-3-P dehydrogenase, 80 nkat 3-phosphoglyceric phosphokinase, 80 nuked creatine-phosphokinase and $0.25 \mathrm{mM} \mathrm{NADH}$.

\subsection{Free polyamine contents and polyamine oxidase activity}

From the starting day of the spraying, with the 7 day intervals, free polyamine contents were determined by the procedure of Aziz and Larher (1995) with a slight modification. leaves $(500 \mathrm{mg})$ were homogenized in $1 \mathrm{ml} 6 \%(\mathrm{v} / \mathrm{v})$ cold perchloric acid, after that centrifuged at 21,000 g for $45 \mathrm{~min}$. The supernatant 
was collected and benzoylated. The benzoyl products were separated and analyzed using HPLC (Model Waters 600E, Waters Inc., USA). From each sample, 10 $\mu 1$ acetonitrile solution of benzoyl polyamines was injected into a $\mathrm{C} 18$ reverse-phase column with $5 \mu \mathrm{m}$ particle size. Column temperature was kept at $30^{\circ} \mathrm{C}$. Prepared samples were eluted from the column with $40 \%$ acetonitrile at a flow rate of $1 \mathrm{ml} \mathrm{min}{ }^{-1}$. The eluent peaks with their retention times (RT) and areas were recorded by an attached Integrator. The standards $(\mathrm{Pu}-$ trescine, Spermidine and Spermine) were purchased from Sigma Chemical Co (Missouri, USA).

Polyamine oxidase activity was measured spectrophotometrically. For enzyme extraction, leaf samples were homogenized in potassium phosphate buffer (1.6 $\mathrm{mL} ; 0.1 \mathrm{M}, \mathrm{pH}$ 6.7). Then, the mixtures centrifuged at $12,000 \mathrm{~g}$ for $15 \mathrm{~min}$ at $4{ }^{\circ} \mathrm{C}$. The supernatant solutions were collected and used for enzyme assays with a UV visible spectrophotometer at $550 \mathrm{~nm}$ (100 Conc UV Visible Spectrophotometer, Varian, California, USA) according to the method described by Smith (1972). A $0.5 \mathrm{ml}$ of $25 \mathrm{mM}, \mathrm{HCl}$ salt was used as substrate. One unit of enzyme activity is defined as 0.001 absorbance units of change in the optical density at $550 \mathrm{~nm} \mathrm{~min}^{-1}$.

\subsection{Antioxidant enzyme assay}

Leaf samples $(0.5 \mathrm{~g})$ were homogenized with $3 \mathrm{ml}$ icecold extraction buffer (0.05 M Tris-Hcl buffer, $\mathrm{pH} 7.5$, $3 \mathrm{mM} \mathrm{MgCl}_{2}, 1 \mathrm{mM}$ EDTA), with the addition of $2 \mathrm{mM}$ Na-ascorbate in case of ascorbate peroxidase assay. The homogenate was centrifuged at $8000 \mathrm{~g}$ for $30 \mathrm{~min}$ at $4{ }^{\circ} \mathrm{C}$, and the supernatant filtered through Whatman No. 10 filter paper. The supernatant fraction was used as a crude enzyme extract for further assay of enzyme activities. All assays were performed at $4{ }^{\circ} \mathrm{C}$. The activity of peroxidase (POX) was determined by following the change in absorbance at $420 \mathrm{~nm}$ due to the formation of guaiacol oxidation. POX activity was analyzed for $2 \mathrm{~min}$ in a solution in- cluding $2.5 \mathrm{ml}$ of $50 \mathrm{mM}$ potassium phosphate buffer $(\mathrm{pH}$ 7.0), $1 \mathrm{ml}$ of $1 \%$ guaiacol, $1 \mathrm{ml}$ of $1 \% \mathrm{H}_{2} \mathrm{O}_{2}$ and $0.3 \mathrm{ml}$ of enzyme extract (Gueta-Dahan et al., 1997). The enzyme activity was estimated using the extinction coefficient of tetra-guaiacol, an oxidation product of guaiacol. In this study ascorbate peroxidase (APX) activity was measured spectrophotometrically by monitoring the decrease in absorbance due to ascorbate oxidation at $290 \mathrm{~nm}$ (Nakano and Asada, 1981). The assay solution included $0.1 \mathrm{mM}$ EDTA, $2.5 \mathrm{ml}$ of $50 \mathrm{mM}$ potassium phosphate buffer $(\mathrm{pH}$ 7.0), $1.2 \mathrm{mM} \mathrm{H}_{2} \mathrm{O}_{2}, 1 \mathrm{mM}$ sodium ascorbate and $0.1 \mathrm{ml}$ of enzyme extract. One unit of superoxide dismutase (SOD) activity was defined as the amount of enzyme in a sample solution affecting $50 \%$ of the maximum inhibition of nitro blue tetrazolium (NBT) reduction. Catalase (CAT) activity was analyzed by monitoring the loss of $\mathrm{H}_{2} \mathrm{O}_{2}$ at $240 \mathrm{~nm}$ (Aebi, 1984). The reaction mixture comprised of $1 \mathrm{mM}$ EDTA, $2.5 \mathrm{ml}$ of $50 \mathrm{mM}$ K-phosphate buffer $(\mathrm{pH}$ 7.0), $0.2 \mathrm{ml}$ of $1 \% \mathrm{H}_{2} \mathrm{O}_{2}$ and $0.3 \mathrm{ml}$ enzyme extract. Polyphenol oxidase (PPO) activity was determined following the procedure of Kumar and Khan (1982). Total soluble protein content was estimated by using bovine serum albumin (BSA) as a protein standard according to Bradford (1976). Fresh leaf samples (1 g) were homogenized with $4 \mathrm{ml}$ Na- Phosphate buffer ( $\mathrm{pH}$ 7.2) and then centrifuged at $12,000 \mathrm{~g}$ at $4{ }^{\circ} \mathrm{C}$. Supernatants and dye were pipetted into cuvettes and absorbance was noted using a UV-vis spectrophotometer (PG instruments T80) at $595 \mathrm{~nm}$.

2.8. Lipid peroxidation, hydrogen peroxide, singlet oxygen contents and membrane stability index

Lipid peroxidation in leaf tissue was determined by measuring malondialdehyde (MDA) (Heath and Packer, 1968). The leaf tissues (100 mg) were ground in $2.5 \mathrm{ml}$ of trichloroacetic acid $(0.1 \%, \mathrm{w} / \mathrm{v})$ and homogenates centrifuged at $15,000 \mathrm{~g}$ for $10 \mathrm{~min}$ at $4{ }^{\circ} \mathrm{C}$. An equal volume of supernatant and $0.5 \%$ thiobarbituric acid (TBA) were added to $20 \%$ TCA, followed by heat- 
ing at $96{ }^{\circ} \mathrm{C}$ for $30 \mathrm{~min}$, and then cooled in ice for 5 $\min$. The absorbance was recorded in 532 and $600 \mathrm{~nm}$. The hydrogen peroxide content of the samples was measured after reaction with potassium iodide (KI) according to the methods described by Velikova et al., (2000). Fresh samples $(1 \mathrm{~g})$ were homogenized in $5 \mathrm{ml}$ of $0.1 \%$ trichloro-acetic acid (TCA), and centrifuged at 12,000 g for $15 \mathrm{~min}$. A $0.5 \mathrm{~mL}$ of the supernatant was added to 0.5 $\mathrm{mL}$ of K-phosphate buffer (10 mM, pH 7) and $1 \mathrm{~mL}$ of 1 M KI. Finally, the absorbance was noted at $390 \mathrm{~nm}$.

The content of $\mathrm{O}_{2}^{--}$generation was determined according to the method of Wang and Jiao (2000).

Membrane stability index (MSI), was calculated by recording the electrical conductivity (EC) of leaf tissues in double distilled water at $40{ }^{\circ} \mathrm{C}(\mathrm{EC} 1)$ and 100 ${ }^{\circ} \mathrm{C}$ (EC2) as described by Belkhadi et al., (2010). The MSI was measured using the following equation:

$$
\mathrm{MSI}=\left(1-\left(\frac{\mathrm{EC} 1}{\mathrm{EC} 2}\right)\right) \times 100
$$

\subsection{Nitrogen content in leaves}

After washing the leaves with double-distilled water to removing the dust, the leaves oven dried at $80{ }^{\circ} \mathrm{C}$ for $48 \mathrm{~h}$. The samples were powdered and then nitrogen content was determined by a CHNS elemental analyzer (Elementar-group, Hanau, Germany).

\subsection{Cation analysis in leaves}

A $200 \mathrm{mg}$ of dried leaves was weighed (two weeks after last spraying) and used for determination of potassium $\left(\mathrm{K}^{+}\right)$, calcium $\left(\mathrm{Ca}^{2+}\right)$ and magnesium $\left(\mathrm{Mg}^{2+}\right)$ cation contents. Plant materials were dried at $550{ }^{\circ} \mathrm{C}$ for $8 \mathrm{~h}$ and at that moment dissolved in $5 \mathrm{M} \mathrm{HNO}_{3}$. Flasks were full up to volume $(50 \mathrm{~mL})$ with double-distilled water and analyzed for cation concentrations [ $\mathrm{mg} \mathrm{g}^{-1}$ dry weight (DW)] by atomic absorption spectrophotometry (Shimadzu AA7000, Kyoto, Japan).

\subsection{Grain yield}

At maturity stage, the plants at $1 \mathrm{~m}^{2}$ of the middle part of each plot were separately harvested and grain yields per unit area were recorded.

\subsection{Analysis of variance}

The data were subjected to analysis of variance (ANOVA) in a split-plot experiment on the bases of randomized complete block design (RCBD) with four replications $(\mathrm{n}=4)$ by SAS software version 9.1 (SAS Institute, Cary, NC, USA). In this study, all data were averaged for two years and used for analysis of the mean (ANOM) by Duncan Multiple Range Test (DMRT) at $P<0.05$ probability using MSTATC software. The figures were drawn by Excel software, and values in the figures and tables are the average of four replications and shown as the means and their standard deviations (SD).

\section{Results}

\subsection{Adenosine triphosphate content}

Adenosine triphosphate (ATP) content in mung bean leaves increased by rising days after spraying up to 12-22 days (i.e., full flowering stage), but after that point, ATP content significantly $(P<0.05)$ reduced. These peaks of ATP content under water limitation $(170 \mathrm{~mm})$ reached earlier than well-watered treatment $(70 \mathrm{~mm})$. Moreover, by rising water limitation ATP content in plant leaves significantly $(P<0.05)$ decreased. Under water limitation, reduction in ATP contents started earlier than wellirrigated treatment. In both soil moisture, spraying polyamines significantly increased ATP content in mung bean leaves. Putrescine in compared with the other polyamines showed a better effect on improving the ATP content in leaves (Figure 1). 

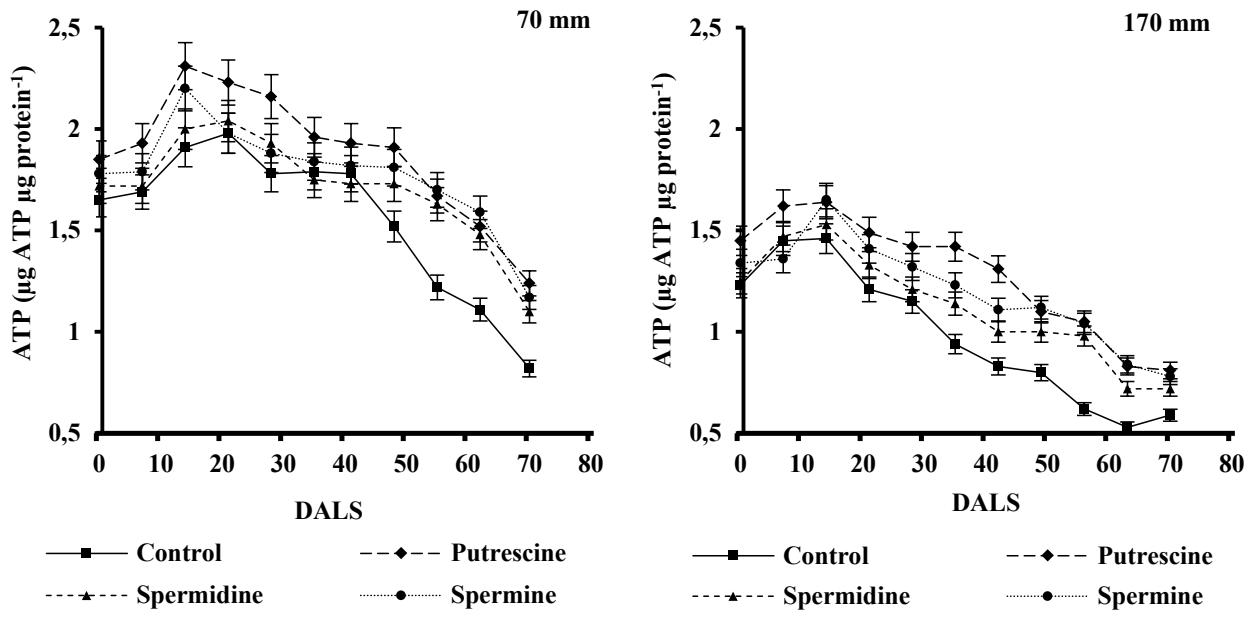

Figure 1. Changes in adenosine triphosphate (ATP) content of mung bean leaves under different water supply (irrigation after 70 and $170 \mathrm{~mm}$ evaporation from class A pan) and polyamines treatment $(0$ and $0.1 \mathrm{mM})$ days after the last spraying (DALS). All values were averaged of two years.

\subsection{Chlorophyll content index}

Chlorophyll content index (CCI) with increasing days after spraying (up to 32-45) did not significantly ( $P$ $<0.05$ ) reduce, after that, however, it reduced by rising days after last spraying of polyamines. Plants under water limitation environment showed lower CCI in comparison with well-irrigated treatment. However, application of polyamines improved CCI under both of the irrigation treatments (Figure 2).
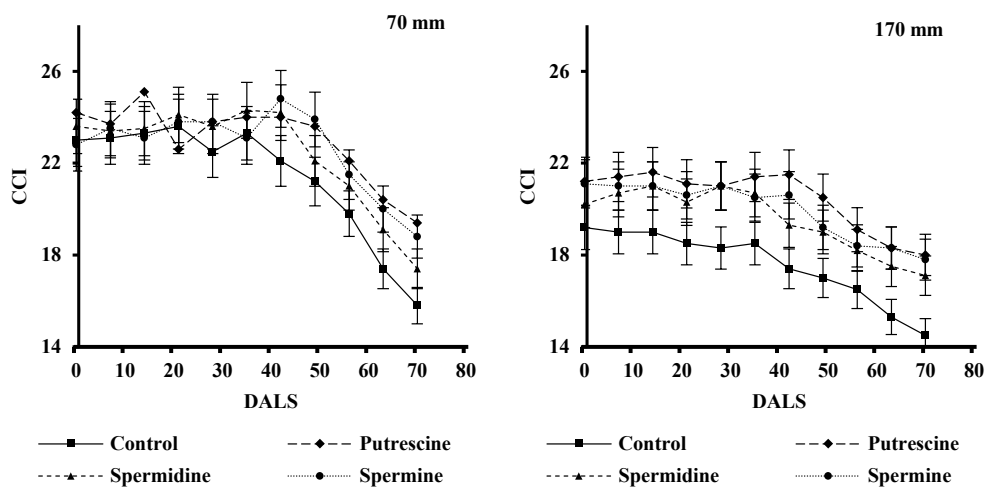

Figure 2. Changes in the chlorophyll content index (CCI) in mung bean leaves under different water supply (irrigation after 70 and $170 \mathrm{~mm}$ evaporation from class A pan) and polyamines treatment $(0$ and $0.1 \mathrm{mM})$ days after the last spraying (DALS). All values were averaged of two years. 


\subsection{Chlorophyll stability index}

The interaction effect of water stress and polyamine treatments was significant $(P \leq 0.01)$ for the chlorophyll stability index (CSI). Results showed that under water limitation, CSI significantly reduced, whereas, under well-irrigated treatment, application of polyamines did not change CSI value in mung bean leaves. However, under water limitation, polyamines spraying, improved the CSI, as the highest CSI (85.2 and 85.4) were achieved from Putrescine and Spermine treatments under well-watered conditions, respectively (Figure 3).

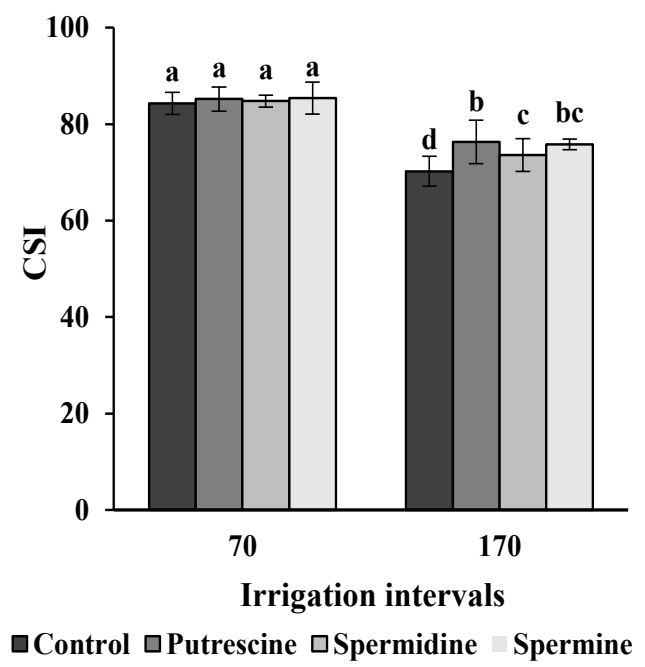

Figure 3. Chlorophyll stability index (CSI) in mung bean plants exposed to different water supply (irrigation after 70 and $170 \mathrm{~mm}$ evaporation from class A pan) and polyamines treatment ( 0 and $0.1 \mathrm{mM})$. All values were averaged of two years. Different letters indicating a significant difference at $P \leq 0.05$.

\subsection{Efficiency of photosystem II ( $F v / F m)$}

Fv/Fm reduced by growing days after last spraying of polyamines and under water limitation. Under wellwatered conditions, the reduction in Fv/Fm started later than water stress condition (Figure 4). Polyamines inhibited the decline of $\mathrm{Fv} / \mathrm{Fm}$ in compared with control plants in both of the irrigation treatments. Moreover, employed treatments inhibited reduction of $\mathrm{Fv} / \mathrm{Fm}$ in last days of plant life cycle (Figure 4). 

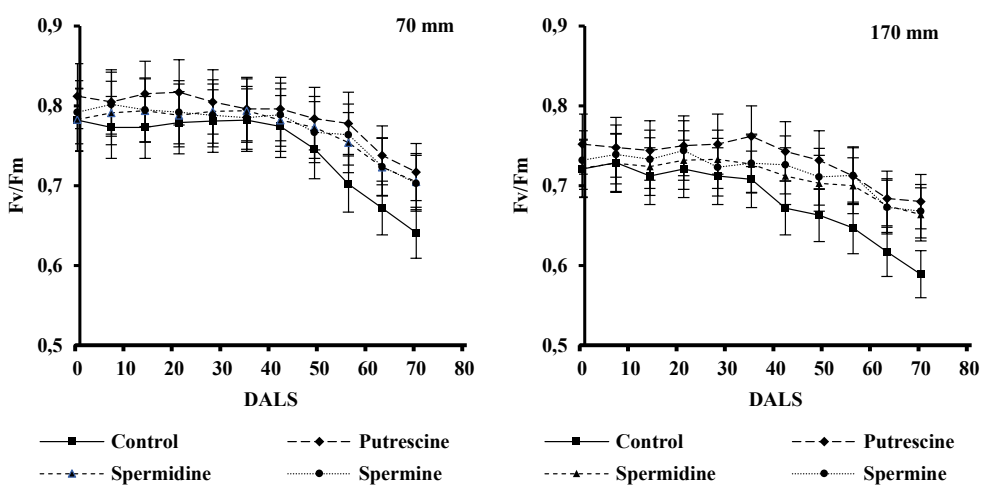

Figure 4. Efficiency of photosystem II (Fv/Fm) in mung bean leaves under different water supply (irrigation after 70 and $170 \mathrm{~mm}$ evaporation from class $\mathrm{A}$ pan $)$ and polyamines treatment $(0$ and $0.1 \mathrm{mM})$ days after the last spraying (DALS). All values were averaged of two years.

\subsection{Rubisco activity}

Initial rate of rubisco activity significantly reduced under water stress condition $(170 \mathrm{~mm})$. Also, this enzyme activity was declined in the last days of experiments in all of the polyamines and control treatments (Figure 5). Foliar application of polyamines under both irrigation treatments remarkably improved rubisco activity. Putrescine had the best effect on improving rubisco activity in comparison with other polyamine tested (Figure 5).
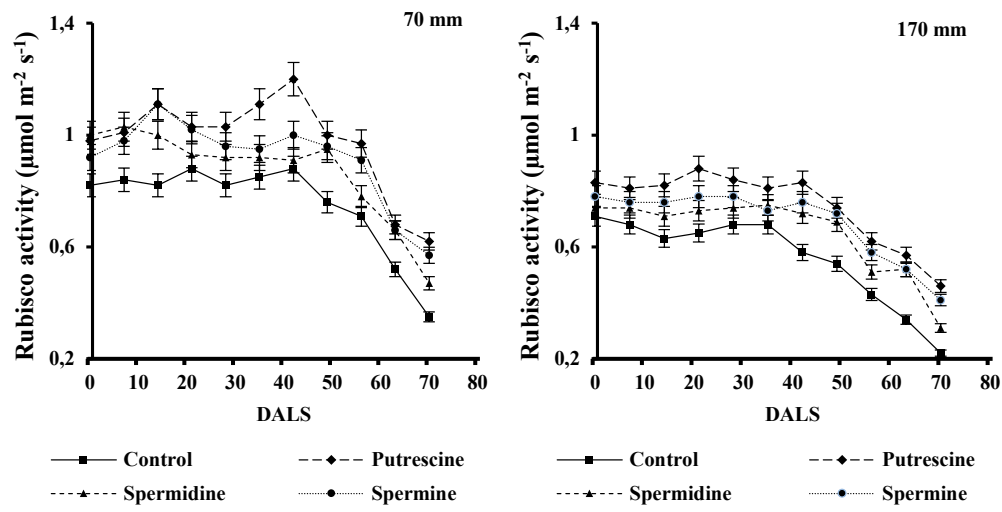

Figure 5. Initial rate of rubisco activity in mung bean leaves under different water supply (irrigation after 70 and $170 \mathrm{~mm}$ evaporation from class A pan) and polyamines treatment ( 0 and $0.1 \mathrm{mM}$ ) days after the last spraying (DALS). All values were averaged of two years. 


\subsection{Free content of polyamines}

Putrescine, Spermidine and Spermine contents in mung bean leaves significantly increased 10-20 days after last spraying, while different polyamine contents reduced with growing days after last spraying. Under water deficit condition, the endogenous content of polyamines decreased to some extent. Spraying each of the polyamines raised the endogenous contents of aforesaid polyamines in mung bean leaves (Figure 6).
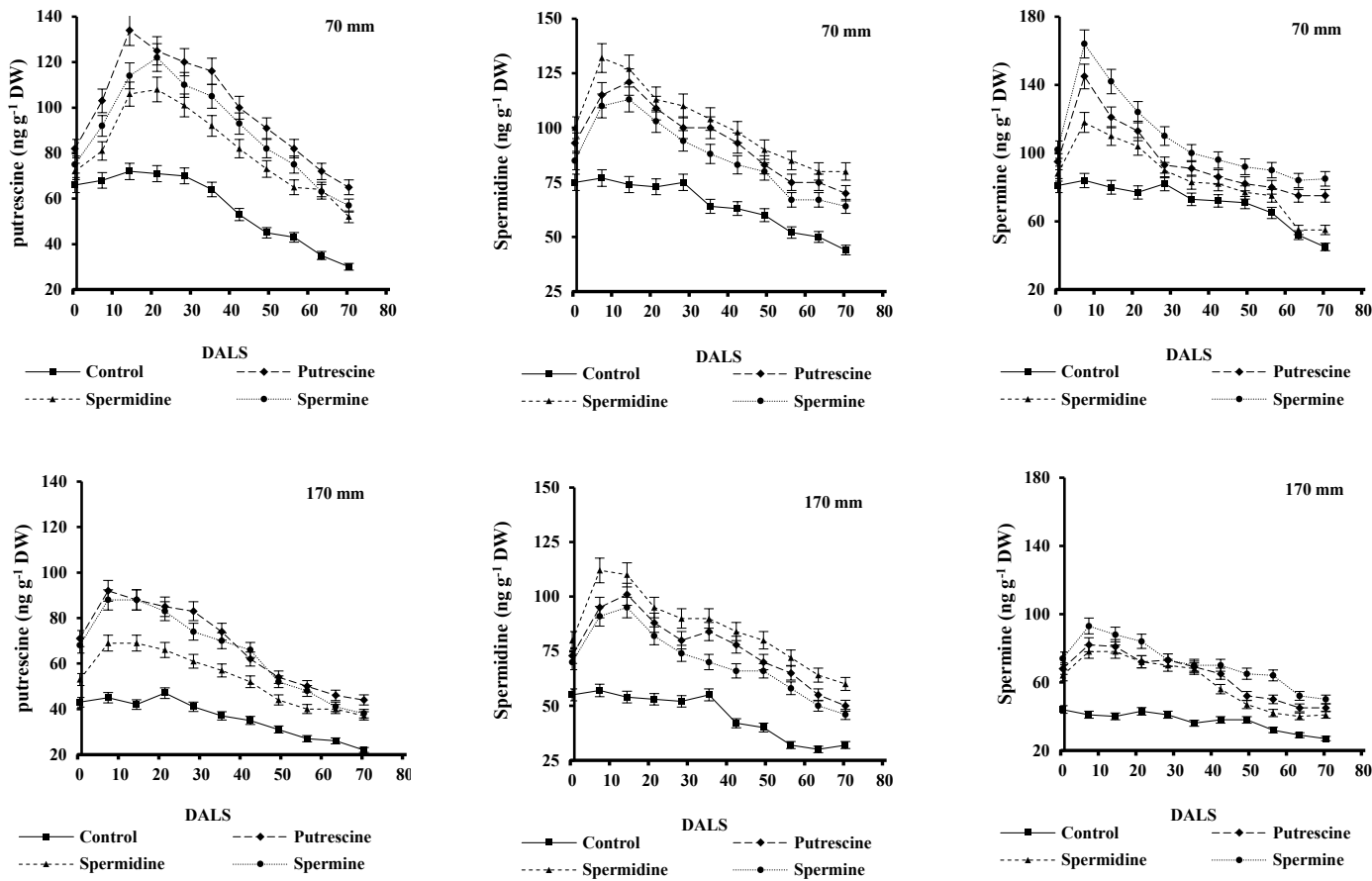

Figure 6. Changes in free polyamine contents in mung bean leaves under different water supply (irrigation after 70 and $170 \mathrm{~mm}$ evaporation from class A pan) and polyamines treatment $(0$ and $0.1 \mathrm{mM})$ days after the last spraying (DALS). All values were averaged of two years.

\subsection{Polyamine oxidase activity}

The activity of polyamine oxidase increased with growing days after last spraying of polyamines. Water deficit significantly $(P \leq 0.01)$ increased the polyamine oxidase activity. According to our results, foliar application of polyamines initially reduced the polyamine oxidase activity in mung bean leaves, but with rising days after last spraying time, the activity enhanced. Spraying of 
polyamines significantly decreased the polyamine oxidase activity in mung bean leaves in compared with control plants. The lowest activities of polyamine oxidase (141 $\mathrm{U} \mathrm{g}^{-1} \mathrm{DW}$ and $199 \mathrm{U} \mathrm{g}^{-1} \mathrm{DW}$ )

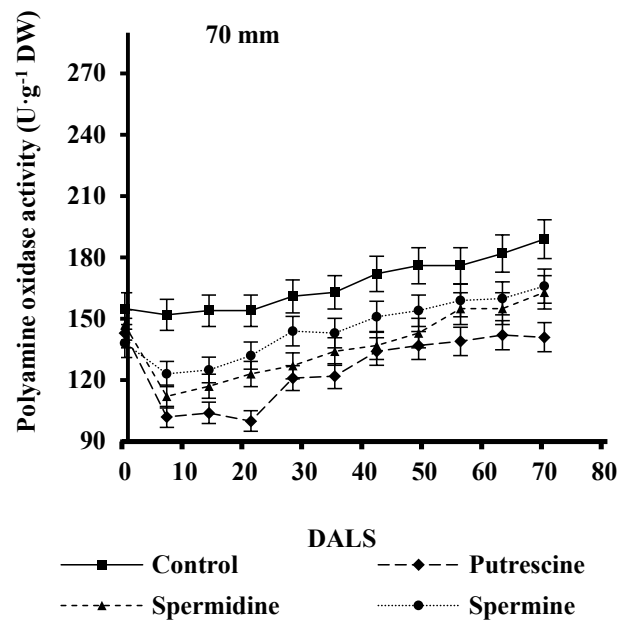

were observed in plants treated with Putrescine under well-watered and water deficit stress, respectively, followed by Spermidine and Spermine treatments (Figure 7).

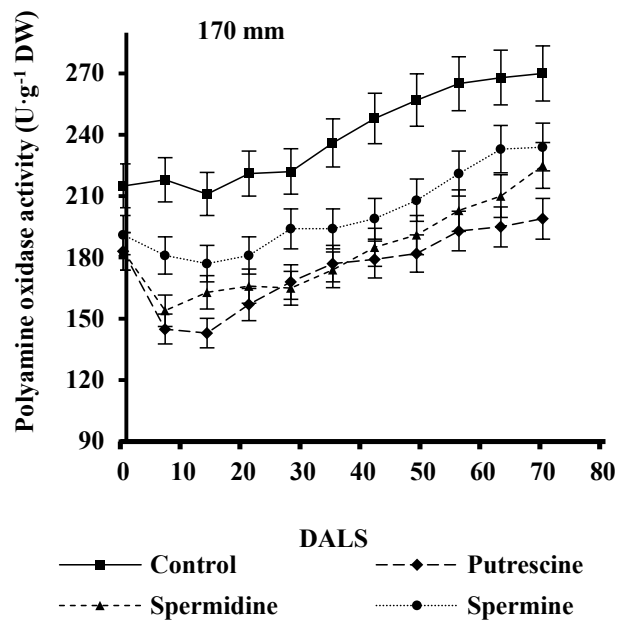

Figure 7. Changes in polyamine oxidase activity in mung bean leaves under different water supply (irrigation after 70 and $170 \mathrm{~mm}$ evaporation from class A pan) and polyamines treatment ( 0 and $0.1 \mathrm{mM})$ days after the last spraying (DALS). All values were averaged of two years.

\subsection{Antioxidant enzymes activity}

All of the antioxidant enzyme activities significantly $(P \leq 0.01)$ affected by the interaction of water stress and polyamine treatments. The activities of antioxidant enzymes increased under water deficit conditions, however, application of polyamines significantly $(P$ $\leq 0.01)$ increased the activities of all antioxidant enzymes. Also, under well-watered treatment employed polyamines, Putrescine, Spermidine and Spermine, significantly increased the activities of peroxidase (POX, by $28.8 \%, 38.4 \%$, and $31.9 \%$ ), ascorbate peroxidase (APX, by $29.7 \%, 20 \%$ and $25.7 \%$ ) and superoxide dismutase (SOD, by $25.3 \%, 31.1 \%$ and $19.48 \%$ ), respectively. There was no significant difference between Spermidine and Spermine uses with control on catalase (CAT) activity under employed irrigation treatments. However, polyamines application had no significant effect on polyphenol oxidase (PPO) activity under well-watered treatment (Table 2). 
Table 2. Means \pm standard error of antioxidant enzymes activity $\left(\mathrm{U} \mathrm{g}^{-1} \mathrm{FW}\right)$ in mung bean leaves under different irrigation intervals and polyamine treatments (values were averaged of two years).

\begin{tabular}{|c|c|c|c|c|c|c|}
\hline $\begin{array}{c}\text { Irrigation } \\
\text { Intervals (mm) }\end{array}$ & $\begin{array}{l}\text { Polyamines } \\
(0.1 \mathrm{mM})\end{array}$ & 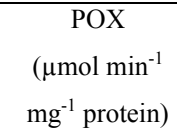 & 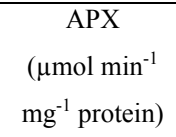 & 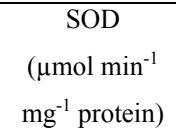 & 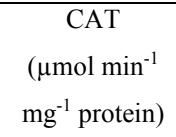 & 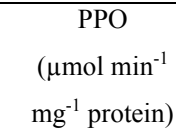 \\
\hline \multirow{4}{*}{70} & 0 & $0.32 \pm 0.04 \mathrm{~g}$ & $0.52 \pm 0.14 \mathrm{~g}$ & $0.62 \pm 0.05 \mathrm{~g}$ & $0.33 \pm 0.01 \mathrm{f}$ & $0.96 \pm 0.03 \mathrm{fe}$ \\
\hline & Putrescine & $0.45 \pm 0.07 \mathrm{f}$ & $0.74 \pm 0.10 \mathrm{e}$ & $0.83 \pm 0.05 \mathrm{ef}$ & $0.45 \pm 0.03 \mathrm{e}$ & $0.93 \pm 0.04 \mathrm{f}$ \\
\hline & Spermidine & $0.52 \pm 0.01 \mathrm{e}$ & $0.65 \pm 0.09 \mathrm{f}$ & $0.90 \pm 0.02 \mathrm{e}$ & $0.36 \pm 0.12 \mathrm{ef}$ & $1.09 \pm 0.02 \mathrm{e}$ \\
\hline & Spermine & $0.47 \pm 0.09$ ef & $0.70 \pm 0.05 \mathrm{e}$ & $0.77 \pm 0.04 \mathrm{f}$ & $0.30 \pm 0.05 \mathrm{f}$ & $1.18 \pm 0.08 \mathrm{e}$ \\
\hline \multirow{4}{*}{170} & 0 & $4.12 \pm 0.11 \mathrm{~d}$ & $6.31 \pm 0.11 \mathrm{~d}$ & $3.65 \pm 0.11 \mathrm{~d}$ & $2.10 \pm 0.06 \mathrm{~d}$ & $7.23 \pm 0.12 \mathrm{~d}$ \\
\hline & Putrescine & $4.89 \pm 0.03 \mathrm{a}$ & $8.62 \pm 0.14 \mathrm{a}$ & $5.32 \pm 0.17 \mathrm{~b}$ & $2.67 \pm 0.09 \mathrm{~b}$ & $9.26 \pm 0.24 \mathrm{a}$ \\
\hline & Spermidine & $4.23 \pm 0.07 \mathrm{c}$ & $7.54 \pm 0.02 \mathrm{c}$ & $5.78 \pm 0.03 \mathrm{a}$ & $2.25 \pm 0.03 \mathrm{c}$ & $8.02 \pm 0.16 \mathrm{c}$ \\
\hline & Spermine & $4.65 \pm 0.08 \mathrm{~b}$ & $6.58 \pm 0.18 b$ & $4.93 \pm 0.06 \mathrm{c}$ & $2.84 \pm 0.12 \mathrm{a}$ & $8.31 \pm 0.11 b$ \\
\hline
\end{tabular}

Different letters indicating significant difference at $P \leq 0.05$

3.9. Lipid peroxidation, hydrogen peroxide, singlet oxygen and membrane stability index

The Interaction effect of water stress and polyamine treatments was significant $(P \leq 0.01)$ for lipid peroxidation (MDA), hydrogen peroxide $\left(\mathrm{H}_{2} \mathrm{O}_{2}\right)$, singlet oxygen $\left(\mathrm{O}_{2}^{-{ }^{-}}\right)$and membrane stability index (MSI). The contents of MDA, $\mathrm{H}_{2} \mathrm{O}_{2}$ and $\mathrm{O}_{2}{ }^{--}$under water stress were increased by $72.8 \%, 58.9 \%$ and $73.5 \%$ over the respective control, respectively, while MSI reduced (by 19.2\%) under such condition. Treatment of plants with polyamines (Putrescine, Spermidine and Spermine) significantly $(P \leq$ 0.01 ) reduced MDA (by $69.1 \%, 51.1 \%$ and $52.3 \%$ ) and $\mathrm{O}_{2}^{-{ }^{-}}$(by $71.4 \%, 42.8 \%$ and $50 \%$ ) under wellwatered and limited irrigation (by $48.1 \%, 18.7 \%$ and $16.2 \%$ ) and (by $96.2 \%, 29.2 \%$ and $39.4 \%$ ), respectively. On the other hand, Putrescine compared with other polyamines showed a better effect on reducing of cellular injury indices. The content of $\mathrm{H}_{2} \mathrm{O}_{2}$ under well-watered only reduced upon application of Putrescine, and other polyamine treatments did not show any improvements in the $\mathrm{H}_{2} \mathrm{O}_{2}$ content, however, under water deficit condition, all of the polyamine treatments significantly ( $P \leq$ 0.01 ) decreased $\mathrm{H}_{2} \mathrm{O}_{2}$ content. Polyamine treatments improved MSI of mung bean leaves in both of the irrigation treatments (Table 3). 
Table 3. Means \pm standard error of lipid peroxidation (MDA), hydrogen peroxide $\left(\mathrm{H}_{2} \mathrm{O}_{2}\right)$. singlet oxygen $\left(\mathrm{O}_{2}{ }^{-}\right)$ contents and membrane stability index (MSI) in mung bean leaves under different irrigation intervals and polyamine treatments (values were averaged of two years).

\begin{tabular}{cllllc}
\hline $\begin{array}{c}\text { Irrigation } \\
\text { Intervals }(\mathrm{mm})\end{array}$ & $\begin{array}{c}\text { Polyamines } \\
(0.1 \mathrm{mM})\end{array}$ & $\begin{array}{c}\mathrm{MDA} \\
\left(\mathrm{mmol} \mathrm{g}^{-1} \mathrm{FW}\right)\end{array}$ & $\begin{array}{c}\mathrm{H}_{2} \mathrm{O}_{2} \\
(\mu \mathrm{mol} \mathrm{g}\end{array}$ & $\begin{array}{c}\mathrm{O}_{2} \bullet- \\
\left(\mu \mathrm{mol} \mathrm{g}^{-1} \mathrm{FW} \mathrm{h}^{-1}\right)\end{array}$ & $\begin{array}{c}\text { MSI } \\
(\%)\end{array}$ \\
\hline \multirow{3}{*}{70} & 0 & $1.72 \pm 0.12 \mathrm{~d}$ & $0.16 \pm 0.03 \mathrm{c}$ & $0.14 \pm 0.05 \mathrm{~d}$ & $76.20 \pm 2.29 \mathrm{c}$ \\
& Putrescine & $0.53 \pm 0.09 \mathrm{f}$ & $0.05 \pm 0.02 \mathrm{~d}$ & $0.04 \pm 0.05 \mathrm{e}$ & $83.12 \pm 1.02 \mathrm{a}$ \\
& Spermidine & $0.84 \pm 0.14 \mathrm{e}$ & $0.10 \pm 0.02 \mathrm{~cd}$ & $0.08 \pm 0.02 \mathrm{e}$ & $79.56 \pm 1.36 \mathrm{~b}$ \\
& Spermine & $0.82 \pm 0.05 \mathrm{e}$ & $0.13 \pm 0.04 \mathrm{c}$ & $0.07 \pm 0.01 \mathrm{e}$ & $78.23 \pm 0.85 \mathrm{~b}$ \\
\hline \multirow{2}{*}{170} & 0 & $6.34 \pm 0.19 \mathrm{a}$ & $0.39 \pm 0.11 \mathrm{a}$ & $0.53 \pm 0.03 \mathrm{a}$ & $61.54 \pm 1.11 \mathrm{f}$ \\
& Putrescine & $4.28 \pm 0.15 \mathrm{c}$ & $0.25 \pm 0.08 \mathrm{~b}$ & $0.27 \pm 0.11 \mathrm{c}$ & $70.11 \pm 1.74 \mathrm{~d}$ \\
& Spermidine & $5.34 \pm 0.21 \mathrm{~b}$ & $0.27 \pm 0.09 \mathrm{~b}$ & $0.41 \pm 0.04 \mathrm{~b}$ & $68.34 \pm 0.93 \mathrm{~d}$ \\
& Spermine & $5.47 \pm 0.37 \mathrm{~b}$ & $0.23 \pm 0.08 \mathrm{~b}$ & $0.38 \pm 0.04 \mathrm{~b}$ & $66.21 \pm 0.52 \mathrm{e}$ \\
\hline
\end{tabular}

Different letters indicating significant difference at $P \leq 0.05$

\subsection{Nitrogen and cation contents in leaves}

The interaction effect of water stress and polyamine treatments was significant $(P \leq 0.01)$ for nitrogen and cation content in the leaves. Nitrogen $\left(\mathrm{N}_{2}\right)$, potassium $\left(\mathrm{K}^{+}\right)$, calcium $\left(\mathrm{Ca}^{2+}\right)$ and magnesium $\left(\mathrm{Mg}^{2+}\right)$ contents in mung bean leaves under water stress reduced by $24.8 \%$,
$31.3 \%, 46.2 \%$ and $24.8 \%$ over the control, respectively. Polyamine treatments significantly $(p \leq 0.01)$ increased $\mathrm{N}_{2}$ and all tested cation contents of the leaves in both irrigation levels (Table 4). Under water deficit conditions, application of Putrescine and Spermidine showed higher content of $\mathrm{N}_{2}$ (by $12.5 \%$ and $6.4 \%$ ) than Spermine treatment in mung bean leaves, respectively (Table 4 ).

Table 4. Means \pm standard error of nitrogen, cations, plant biomass and grain yield of mung bean plants in different irrigation intervals and polyamine treatments (values were averaged of two years).

\begin{tabular}{clccccc}
\hline $\begin{array}{c}\text { Irrigation } \\
\text { Intervals }(\mathrm{mm})\end{array}$ & $\begin{array}{l}\text { Polyamines } \\
(0.1 \mathrm{mM})\end{array}$ & $\begin{array}{c}\mathrm{N}_{2} \\
\left(\mathrm{mg} \mathrm{g}^{-1} \mathrm{DW}\right)\end{array}$ & $\begin{array}{c}\mathrm{K}^{+} \\
\left(\mathrm{mg} \mathrm{g}^{-1} \mathrm{DW}\right)\end{array}$ & $\begin{array}{c}\mathrm{Ca}^{2+} \\
\left(\mathrm{mg} \mathrm{g}^{-1} \mathrm{DW}\right)\end{array}$ & $\begin{array}{c}\mathrm{Mg}^{2+} \\
\left(\mathrm{mg} \mathrm{g}^{-1} \mathrm{DW}\right)\end{array}$ & $\begin{array}{c}\text { Grain yield } \\
\left.(\mathrm{g} \mathrm{m})^{-2}\right)\end{array}$ \\
\hline \multirow{2}{*}{70} & 0 & $35.23 \pm 0.28 \mathrm{c}$ & $32.34 \pm 0.85 \mathrm{~b}$ & $8.84 \pm 0.17 \mathrm{c}$ & $4.26 \pm 0.12 \mathrm{~d}$ & $210.25 \pm 4.31 \mathrm{c}$ \\
& Putrescine & $39.45 \pm 0.31 \mathrm{a}$ & $36.67 \pm 0.19 \mathrm{a}$ & $14.05 \pm 0.09 \mathrm{a}$ & $5.35 \pm 0.01 \mathrm{~b}$ & $248.00 \pm 3.21 \mathrm{a}$ \\
& Spermidine & $38.97 \pm 0.12 \mathrm{a}$ & $35.11 \pm 0.43 \mathrm{a}$ & $13.92 \pm 0.11 \mathrm{a}$ & $7.23 \pm 0.04 \mathrm{a}$ & $230.11 \pm 5.23 \mathrm{~b}$ \\
& Spermine & $36.54 \pm 0.41 \mathrm{~b}$ & $36.19 \pm 0.82 \mathrm{a}$ & $11.37 \pm 0.05 \mathrm{~b}$ & $4.89 \pm 0.07 \mathrm{c}$ & $231.50 \pm 2.73 \mathrm{~b}$ \\
\hline \multirow{2}{*}{170} & 0 & $26.49 \pm 0.13 \mathrm{f}$ & $22.20 \pm 0.23 \mathrm{e}$ & $4.75 \pm 0.09 \mathrm{e}$ & $3.23 \pm 0.10 \mathrm{f}$ & $110.50 \pm 6.21 \mathrm{f}$ \\
& Putrescine & $30.30 \pm 0.28 \mathrm{~d}$ & $28.43 \pm 0.11 \mathrm{c}$ & $7.21 \pm 0.04 \mathrm{~d}$ & $4.19 \pm 0.02 \mathrm{~d}$ & $141.50 \pm 3.30 \mathrm{~d}$ \\
& Spermidine & $28.31 \pm 0.09 \mathrm{e}$ & $25.64 \pm 0.54 \mathrm{~d}$ & $6.96 \pm 0.12 \mathrm{~d}$ & $4.12 \pm 0.04 \mathrm{~d}$ & $126.01 \pm 7.11 \mathrm{e}$ \\
& Spermine & $28.45 \pm 0.15 \mathrm{e}$ & $25.50 \pm 0.34 \mathrm{~d}$ & $7.03 \pm 0.10 \mathrm{~d}$ & $3.74 \pm 0.08 \mathrm{e}$ & $127.50 \pm 2.29 \mathrm{e}$ \\
\hline
\end{tabular}

Different letters indicating significant difference at $P \leq 0.05$. 


\subsection{Grain yield}

Grain yield of mung bean plants significantly ( $P \leq$ 0.01 ) influenced by irrigation intervals and polyamine treatments. Under water shortage, a significant reduction in grain yield $(47.4 \%)$ was observed in control untreated plants. However, spraying of polyamines including Putrescine, Spermidine and Spermine increased the grain yield of mung bean by $15.2 \%, 8.6 \%$ and $9.1 \%$ in non-stressed, and by $21.9 \%, 12.2 \%$ and $13.3 \%$ in stressed-plants compared to the respective controls, respectively (Table 4).

\section{Discussion}

Polyamines as a new class of plant growth stimulants play essential roles in a range of developmental and physiological processes such as gene expression (Ebeed et al., 2017), protein and DNA synthesis, cell division and differentiation, growth and developmental processes such as somatic embryogenesis, organogenesis, dormancy breaking of tubers and in seed germination, development of flowers and fruits and senescence (Liu et al., 2016).

In the present study, reduction in ATP content (Figure1) under water limitation is attributed to decreasing calcium $\left(\mathrm{Ca}^{2+}\right)$ and magnesium $\left(\mathrm{Mg}^{2+}\right)$ contents in leaves (Table 4). Because these elements with activation of two essential enzymes (Ca-ATPase and $\mathrm{Mg}$ ATPase) have key roles in ATP synthesis in plant cells. Also, inhibition of electron transport of PSII (Fv/Fm) (Figure 4) reduced ATP content of mung bean leaves under water stress condition. Zheng et al., (2009) reported that the reduction in ATP synthesis relates to PSII damages in wheat. Polyamines with improving $\mathrm{Ca}^{2+}$ and $\mathrm{Mg}^{2+}$ contents in leaves and increasing $\mathrm{Fv} /$ Fm improved the ATP content in leaf tissues (Figure 1). Polyamines, due to their proton sequestering capacity, might accept protons from 'producers' (i.e.,
PSII, Cytb6f, PSI) and deliver protons to 'consumers' (ATPase). This may explain why polyamines stimulate ATP synthesis (Ioannidis and Kotzabasis, 2007). Chlorophyll content index (CCI) (Figure 2), chlorophyll stability index (CSI) (Figure 3) and some of the structural elements in chlorophyll body, such as $\mathrm{Mg}^{2+}$ and nitrogen $\left(\mathrm{N}_{2}\right)$ (Table 4) reduced under water stress by increasing oxidative damage (Table 3 ). Polyamines by decreasing oxidative damages of water stress (Table 3 ) and enriching plant cells by $\mathrm{N}_{2}$, potassium $\left(\mathrm{K}^{+}\right)$and $\mathrm{Mg}^{2+}$ (Table 4), increased CCI (Figure 2) and CSI (Figure 3) of mung bean leaves.

Photosynthetic electron transport through photosystem II and Fv/Fm was inhibited by water stress (Figure 4). Moreover, oxidative stress damages under drought stress (Table 3) may induce adverse impact on PSII. A significant implication of PSII photoinactivation process is that non-functional PSII reaction complexes, still capturing plastid pigment molecules, may intensify photo-oxidative stress damage to chloroplasts and thylakoid membranes unless excessive absorbed light energy via photosynthetic pigments is scattered safely (Krause, 1988). Polyamine treatments with increasing antioxidant enzymes (Table 2) under water stress and reducing reactive oxygen species (ROS), reduced oxidative damages to the cell structure (Table 3) and improved Fv/Fm (Figure 4).

Destructive effects of water stress, such as reduction in $\mathrm{K}^{+}$(a key element in enzyme activation) and $\mathrm{N}_{2}$ content (Structural element in enzyme body) (Table 4 ), decrease in cellular energy (Figure 1) and enhancement of ROS and oxidative stress under water stress (Table 3) remarkably decreased the activity of rubisco enzyme in mung bean leaves (Figure 5). Polyamines raised the rubisco activity under water stress (Figure 5). Polyamines conjugation through intracellular transglutaminases, particularly to rubisco seems to have a key regulatory role in protecting this protein from protease activity, therefore defending its 
photosynthetic efficiency. Polyamines with reducing the generation of reactive oxygen species and increasing the antioxidant activities can protect the photosynthetic proteins such as rubisco from the degradation. Thus, polyamines are likely to play an essential role in photosynthesis because they are capable of reversing stress-induced impairment in photosynthetic systems (Sfakianaki et al., 2006).

Polyamine oxidase is a key enzyme in the polyamines degradation in plant cells. Under severe water stress, decreasing polyamines content (Figure 6) can be attributed with increasing activity of this enzyme (Figure 7), whereas several authors reported an increase in polyamines content under water deficit conditions in cotton (Loka et al., 2015) and rice (Yang et al., 2007). Application of polyamines by reducing polyamine oxidase activity (Figure 7), increased endogenous $\mathrm{Pu}$ trescine, Spermidine and Spermine contents of mung bean leaves (Figure 6). Increasing polyamine oxidase activity under water stress is related to the rising gene expression of this enzyme under water stress (Li et al., 2015). Polyamines with amending adverse effects of deficit water stress reduced polyamine oxidase activity of mung bean leaves (Figure 7).

Enhanced antioxidant enzyme activities under water stress (Table 2) can be attributed to elevated hydrogen peroxide $\left(\mathrm{H}_{2} \mathrm{O}_{2}\right)$ and singlet oxygen $\left(\mathrm{O}_{2}^{-{ }^{-}}\right)$contents of mung bean leaves (Table 3 ). In this condition, usually plants raised their antioxidant activities for scavenging ROS. Improved antioxidant activities with polyamine treatments (Table 2) are related to improving molecular signaling to confer adaptive responses of plants under water stress (Toumi et al., 2010). Moreover, application of polyamines by rising endogenous content of polyamines (Figure 6) of mung bean leaves improved antioxidant enzyme activities (Table 2). Previous reports suggest that polyamines can act vital roles in stabilizing membranes, scavenging free radicals by increasing antioxidant activities (Velikova et al., 2000). Also, polyamines through reduction in ethylene synthesis and decrease in leaf senescence improved activity of antioxidant enzymes in plant cells. Enhanced lipid peroxidation (MDA) and decreased membrane stability index with rising water deficit are related with overproduction of $\mathrm{H}_{2} \mathrm{O}_{2}$ and $\mathrm{O}_{2}{ }^{--}$in mung bean leaves (Table 3). Enhanced $\mathrm{H}_{2} \mathrm{O}_{2}$ and $\mathrm{O}_{2}^{-}$levels under water stress (Table 3 ) are linked with excessive ROS produced by inhibition of electron transports specially on the photosystem II system (Figure 4) and enhanced the hill reaction under severe water stress (Bradford and Hsiao, 1982). Polyamines with increasing antioxidant enzyme activities reduced $\mathrm{H}_{2} \mathrm{O}_{2}$ and $\mathrm{O}_{2}{ }^{--}$contents, decreased MDA and improved MSI in mung bean leaves (Table 3).

Water stress causes adverse effects on root development and water potential of root zones, reducing $\mathrm{N}_{2}$, $\mathrm{K}^{+}, \mathrm{Ca}^{2+}$ and $\mathrm{Mg}^{2}$ uptake and translocation in mung bean plants. In contrast, polyamines improved $\mathrm{N}_{2}$, $\mathrm{K}^{+}, \mathrm{Ca}^{2+}$ and $\mathrm{Mg}^{2+}$ uptake and translocation (Table 4) through improving root growth and development and adjusting water potential in plant cells (Gill and Tuteja, 2010). Moreover, enhanced $\mathrm{N}_{2}$ content in mung bean leaves may be attributed to rising nitrate reductase activity by polyamines (Singh et al., 2002). The decreased grain yield of mung bean plants under water stress (Table 4) is associated with negative effects of water stress on physiological and biochemical activities under such conditions (Figures 1-7 and tables 3 and 4). Polyamine treatments increased grain yield (Table 4) with alleviating adverse effects of water stress on most of the physiological traits.

\section{Conclusions}

The results indicate that polyamines improved grain yield of mung bean plants by increasing physiological performance under both well-watered and waterstressed treatments. Application of polyamines by 
decreasing polyamine oxidase activity increased endogenous content of polyamines and reduced ROS generation and subsequent oxidative damage. Also, polyamines improved the efficiency of photosystem II, rubisco activity, chlorophyll content index and chlorophyll stability index under water stress. Polyamine treatments, especially in the last days of plant life cycle increased productivity of mung bean plants under soil water limitation through enhanced physiological performance and increased cell energy status.

\section{References}

Aebi, H. 1984. Catalase in vitro. Methods in enzymology. 105, 121-126.

Aziz, A., Larher, F. 1995. Changes in polyamine titers associated with the proline response and osmotic adjustment of rape leaf discs submitted to osmotic stresses. Plant Sci. 112, 175-186.

Baiazidi-Aghdam MT, Mohammadi H, Ghorbanpour M. 2016. Effects of nanoparticulateanatase titanium dioxide on physiological and biochemical performance of Linum usitatissimum (Linaceae) under well watered and drought stress conditions. Braz J Bot. 39, 139-146.

Baker, N.R., Rosenqvist, E. 2004. Applications of chlorophyll fluorescence can improve crop production strategies: an examination of future possibilities. J. Exp. Bot. 55, 1607-1621.

Belkhadi, A., Hediji, H., Abbes, Z., Nouairi, I., Barhoumi, Z., Zarrouk, M., Chaïbi, W., Djebali, W. 2010. Effects of exogenous salicylic acid pretreatment on cadmium toxicity and leaf lipid content in Linum usitatissimum L. Ecotoxicol. Environ. Saf. 73, 1004-1011.

Bradford, K.J., Hsiao, T.C. 1982. Physiological responses to moderate water stress. In Physiological plant ecology II. Springer Berlin Heidelberg. pp. 263-324.
Bradford, M.M. 1976. A rapid and sensitive method for the quantitation of microgram quantities of protein utilizing the principle of protein-dye binding. Anal. Biochem. 72, 248-254.

Butt, M.S., Batool, R. 2010. Nutritional and functional properties of some promising legumes protein isolates. Pak. J. Nutr. 9, 373-379.

Ebeed, H.T., Hassan, N.M., Aljarani, AM. 2017. Exogenous applications of Polyamines modulate drought responses in wheat through osmolytes accumulation, increasing free polyamine levels and regulation of polyamine biosynthetic genes. Plant Physiol Biochem. 118, 438-448.

Flexas, J., Ribas-Carbó, M., Bota, J., Galmés, J., Henkle, M., Martínez-Cañellas, S., Medrano, H. 2006. Decreased Rubisco activity during water stress is not induced by decreased relative water content but related to conditions of low stomatal conductance and chloroplast $\mathrm{CO}_{2}$ concentration. New Phytol. 172, 73-82.

Gill, S.S., Tuteja, N. 2010. Polyamines and abiotic stress tolerance in plants. Plant Signal. Behav. 5, 26-33.

Gueta-Dahan, Y., Yaniv, Z., Zilinskas, B.A., BenHayyim, G. 1997. Salt and oxidative stress: similar and specific responses and their relation to salt tolerance in citrus. Planta. 203, 460-469.

Heath, R.L., Packer, L. 1968. Photoperoxidation in isolated chloroplasts: I. Kinetics and stoichiometry of fatty acid peroxidation. Arch. Biochem. Biophys. 125, 189-198.

Ioannidis, N.E., Kotzabasis, K. 2007. Effects of polyamines on the functionality of photosynthetic membrane in vivo and in vitro. Biochim. Biophys. Acta. 1767, 1372-1382.

Koleyoreas, S.A. 1958. A new method for determining drought resistance. Plant Physiol. 33, 22.

Krause, G.H. 1988. Photoinhibition of photosynthesis. An evaluation of damaging and protective mechanisms. Physiol. Plant. 74, 566-574. 
Kumar, K.B., Khan, P.A. 1982. Peroxidase and polyphenol oxidase in excised ragi (Eleusine corocana cv PR 202) leaves during senescence. Indian J. Exp. Biol. 20, 412-416.

Larsson, C.M., Olsson, T. 1979. Firefly assay of adenine nucleotides from algae: Comparison of extraction methods. Plant Cell Physiol. 20, 145-155.

Li, Z., Zhou, H., Peng, Y., Zhang, X., Ma, X., Huang, L., Yan, Y. 2015. Exogenously applied spermidine improves drought tolerance in creeping bentgrass associated with changes in antioxidant defense, endogenous polyamines and phytohormones. Plant Growth Regul. 76, 71-82.

Limousin, J., Misson, L., Lavoir, A.V., Martin, N.K., Rambal, S. 2010. Do photosynthetic limitations of evergreen Quercus ilex leaves change with longterm increased drought severity? Plant Cell Environ. 33, 863-875.

Liu, Y., Liang, H., Lv, X., Liu, D., Wen, X., Yuncheng Liao, Y. 2016. Effect of polyamines on the grain filling of wheat under drought stress. Plant Physiology and Biochemistry. 100, 113-129.

Lobo, A.K.M., de Oliveira Martins, M., Neto, M.C.L., Machado, E.C., Ribeiro, R.V., Silveira, J.A.G. 2015. Exogenous sucrose supply changes sugar metabolism and reduces photosynthesis of sugarcane through the down-regulation of Rubisco abundance and activity. J. Plant Physiol. 179, 113-121.

Loka, D.A., Oosterhuis, D.M., Pilon, C. 2015. Endogenous levels of polyamines under water-deficit stress during cotton's reproductive development. Am. J. Plant Sci. 6, 344-354.

Mohammadi, H., Ghorbanpour, M., Brestic M. 2018. Exogenous putrescine changes redox regulations and essential oil constituents in field-grown Thymus vulgaris L. under wellwatered and drought stress conditions. Ind Crops Prod. 122, 119-132.
Mustafavi, S.H., Naghdi Badi, H., Sękara, A. Mehrafarin, A., Janda, T., Ghorbanpour, M., Rafiee, H. 2018. Polyamines and their possible mechanisms involved in plant physiological processes and elicitation of secondary metabolites. Acta Physiol Plant. 40: 102.

Munne-Bosch, S., Penuelas, J. 2003. Photo-and antioxidative protection, and a role for salicylic acid during drought and recovery in field-grown Phillyrea angustifolia plants. Planta. 217, 758766.

Nakano, Y., Asada, K., 1981. Hydrogen peroxide is scavenged by ascorbate-specific peroxidase in spinach chloroplasts. Plant Cell Physiol. 22, 867-880.

Sfakianaki, M., Sfichi, L., Kotzabasis, K. 2006. The involvement of LHCII-associated polyamines in the response of the photosynthetic apparatus to low temperature. J. Photochem. Photobiol. B: Biol. 84, 181-188.

Singh, D.B., Varma, S., Mishra, S.N. 2002. Putrescine effect on nitrate reductase activity, organic nitrogen, protein, and growth in heavy metal and salinity stressed mustard seedlings. Biol. Plantarum. 45, 605-608.

Smith, T.A. 1972. Purification and properties of the polyamine oxidase of barley plants. Phytochem. 11, 899-910.

Toumi, I., Moschou, P.N., Paschalidis, K.A., Bouamama, B., Salem-Fnayou, A.B., Ghorbel, A.W., Mliki, A., Roubelakis-Angelakis, K.A. 2010. Abscisic acid signals reorientation of polyamine metabolism to orchestrate stress responses via the polyamine exodus pathway in grapevine. J. Plant Physiol. 167, 519-525.

Velikova, V., Yordanov, I., Edreva, A. 2000. Oxidative stress and some antioxidant systems in acid raintreated bean plants: protective role of exogenous polyamines. Plant Sci. 151, 59-66. 
Wang, S.Y., Jiao, H. 2000. Scavenging capacity of berry crops on superoxide radicals, hydrogen peroxide, hydroxyl radicals, and singlet oxygen. J. Agr. Food Chem. 48, 5677-5684.

Yang, J., Zhang, J., Liu, K., Wang, Z., Liu, L. 2007. Involvement of polyamines in the drought resistance of rice. J. Exp. Bot. 58, 1545-1555.
Zheng, C., Jiang, D., Liu, F., Dai, T., Jing, Q., Cao, W. 2009. Effects of salt and waterlogging stresses and their combination on leaf photosynthesis, chloroplast ATP synthesis, and antioxidant capacity in wheat. Plant Sci. 176, 575-582. 